\title{
Tentative Research on English Teaching Methodology and Learning Style
}

\author{
Jing MENG \\ School of Foreign Languages \\ Jilin Agricultural University \\ Changchun ,Jilin,130118, China
}

\begin{abstract}
In recent years, theories on EFL learners' learning styles have aroused great interests. Studies on the relation between the learners' learning style preference and their language performance have become increasingly popular. In this thesis, researches are made to discover the influence and the effect of two different teaching methodologies (teachercentered and students-centered) on students with different learning style preferences. The author chooses the non-English majors from University of Shanghai for Science and Technology as the subjects and, with the help of statistical data collected, focuses on the analysis of correlation between teaching methodologies used by the teacher and preferred learning styles on the part of students. It is hoped that this research could provide tentative suggestions for the advancement of today' s college English teaching.
\end{abstract}

Keywords- Teaching Methodology, Teacher-Centered, Learner-Centered, Learning Style

\section{INTRODUCTION}

To reduce teacher-student style conflicts, some researchers in the area of learning styles advocate teaching methodologies and learning styles be matched (Griggs \& Dunn, 1984; Smith \& Renzulli, 1984; Charkins et al, 1985), especially in foreign language instruction (Oxford et al, 1991; Wallace \& Oxford, 1992). Kumaravadivelu (1991:98) states that: "... the narrower the gaps between teacher intention and learner interpretation, the greater are the chances of achieving desired learning outcomes". There are many indications (Van Lier, 1996; Breen, 1998) that can bridge the gap between teachers' and learners' perceptions and can play important roles in enabling students to maximize their classroom experience.

Ellis (1989) describes a learning style as the more or less consistent way in which a person perceives, conceptualizes, organizes and recalls information. Students' learning styles will be influenced by their genetic make-up, their previous learning experiences, the culture and the society they live in.

Sue Davidoff (1990) suggests that: Students learn better and more quickly if the teaching methods used match their preferred learning styles. As learning improves, so does students' self-esteem. This has a further positive effect on learning. Students who have become bored with learning may become interested once again. The student-teacher relationship can improve because the student is more successful and is more interested in learning.

Each student has personal learning styles, and these styles can be generalized into categories. The paper describes how teachers can identify which styles are present in their classrooms and how these affect teaching methodologies. It also gives general advice on how to adjust teaching methodologies in order to accommodate the most common learning styles.

In this paper, different ways are described to make this adjustment feasible in real-life classroom settings of today's college English teaching. The assumption underlying the approach taken here is that the way we teach should adapt to the way in which learners learn. Two most frequently used teaching methodologies are chosen to be considered in this research: one is teacher-centered teaching method; the other is learner-centered teaching method.

This paper consists mainly of four parts, and it focuses on the studies on the relation between college students' learning styles and teachers' teaching methodologies.

\section{Perceptual Learning Style Preference (PLSP) SURVEY}

The instrument used in current study is the Perceptual Learning Style Preference Questionnaire (PLSPQ) developed by Reid (1987) (see Appendix I ). It is a self-reporting questionnaire developed on the basis of existing learning style instruments with some changes suggested by nonnative speaker informants and US consultants in the field of linguistics. The questionnaire, which was designed and validated for non-native speakers, consists of five statements on each of the six learning style preferences to be measured: visual, auditory, kinesthetic, tactile, group learning, and individual learning. The first four categories constitute the perceptual learning style categories and the remaining two make up the social category. The participants respond on the basis of a five point Likert (1932) scale, ranging from "strongly agree" to "strongly disagree".

While answering the statements in the questionnaire the students are asked to decide whether they strongly agree, agree, are undecided, disagree, and strongly disagree and mark the items that best applies to their study of English. The participants are also asked to respond to each statement quickly, without thinking about the statements too much and they are asked not to change their responses after they mark them.

During the piloting of the test, the issues, such as students' claims that they have difficulty in differentiating two items from one another and even spelling mistakes raised by the students, are taken into consideration.

The piloting of the questionnaire also helps to determine the time that would be given to students during the actual administration of the questionnaire. The students are able to complete the questionnaire in 15 minutes and the calculation of the results takes around 10 minutes. Depending on the 
timing during the piloting, it is decided that half an hour is ideal for students to respond to the questions, transfer them on the scoring sheet, and find the totals for each category. Based on the students' responses to the questionnaire, the reliability coefficiency of the questionnaire is found.

Since Reid's investigation, many teacher-researchers have used the PLSP informally to help their students identify their individual learning styles. Teachers have also begun to administer the PLSP surveys in EFL programs in nonEnglish speaking countries. The investigations described in the studies below are not comparable in statistical terms: the number of students and the kinds of students differ. Yet the data gathered can be discussed in terms of general trends and be compared in general with Reid's original study. More importantly, the trends described can be studied by other ESL/EFL teachers as they put their own classroom research in practice.

\section{DESCRIPTION OF TESTS}

The pre-test and the post-test (see Appendix IV) in this research are designed approximately of the same difficulty. Both of them are mainly chosen from PETS II or CET4. These tests include exercises on English listening, reading and writing. These three abilities represent the most important aspects of English proficiency according to the requirements of today's College English teaching and learning. In the part of listening comprehension, there are 15 short conversation questions and another 15 questions for 4 short passages respectively. In the part of reading comprehension, there are 5 passages with all-together 20 questions. And in the writing part, students are asked to write a short passage of 100-120 words under certain title and instruction. The time allotment for both tests is 90 minutes and the total score of both tests is 100 , of which $30 \%$ is for listening, $50 \%$ is for reading, and $20 \%$ is for writing.

\section{TEaching Plan on How to Conduct a Teacher- CENTERED Class}

\section{A. Rationale for the Class Plan}

In a teacher-centered classroom, where the teacher, who is the authority figure, makes all the decisions, learners are sometimes passive. The teacher may attempt to maximize their delivery of information and control of the class by emphasizing on the use of lecture technique and questioning. This teacher-centered approach (Izumi, 2001) commonly takes the form of the note-taking/lecture model. Large volume of information is shared in a short amount of time; and the teacher has total control of organization, pacing, and content of what language abilities should be learned. By this teaching method, the teacher can also generally employ quick and easy assessment methods as well as inspire and stimulate students. Students could learn more efficiently when their teachers first structure new information for them and help them relate it to what they have already known, and then monitor their performance and provide corrective feedback during recitation, drill, practice, or application activities.

\section{B. General Framework for the Class Plan}

The lesson plan and supporting activities are designed for the students with the general framework of teacher-centered pedagogy.

Text: Public Attitude towards Science (see AppendixIII) Type of class: Intensive English Class (for Class A) Objectives of the lesson:

- language oriented objective: to help the students grasp key language points embodied in the text;

- knowledge oriented objective: to learn what is the appropriate attitude to science;

- skill oriented objective: to develop listening, speaking, reading, and writing skills.

Length of class: 90 minutes 
TABLE 1. Curriculum

\begin{tabular}{|c|c|c|c|}
\hline $\begin{array}{c}\text { Time } \\
\text { Duration }\end{array}$ & $\begin{array}{c}\text { Lesson } \\
\text { Procedure/Activities }\end{array}$ & Description & Purpose \\
\hline $\begin{array}{c}2 \\
\text { minutes }\end{array}$ & $\begin{array}{l}\text { The teacher sets overall } \\
\text { purpose for reading this text }\end{array}$ & $\begin{array}{l}\text { To learn the key language points and to } \\
\text { grasp the required reading skills. To grasp } \\
\text { the skills of how to write an exposition }\end{array}$ & $\begin{array}{l}\text { To let the students be } \\
\text { aware of what they are } \\
\text { expected to learn. }\end{array}$ \\
\hline $\begin{array}{c}10 \\
\text { minutes }\end{array}$ & $\begin{array}{l}\text { The teacher introduces the } \\
\text { text }\end{array}$ & $\begin{array}{l}\text { Background information about } \\
\text { Stephen Hawking and about the text }\end{array}$ & $\begin{array}{l}\text { To help the students } \\
\text { understand the text in a more } \\
\text { sensible way }\end{array}$ \\
\hline $\begin{array}{c}3 \\
\text { minutes }\end{array}$ & $\begin{array}{l}\text { The students skim the whole } \\
\text { text }\end{array}$ & $\begin{array}{l}\text { The students perform silent and speed } \\
\text { reading of the text. }\end{array}$ & $\begin{array}{l}\text { To help the students get } \\
\text { the overall view of the text } \\
\text { and find out where difficulties } \\
\text { lie in the process. }\end{array}$ \\
\hline $\begin{array}{c}30 \\
\text { minutes }\end{array}$ & Vocabulary study & $\begin{array}{l}\text { The teacher explains new words and } \\
\text { expressions to help the students learn them } \\
\text { by meaning-explanation, example-giving, } \\
\text { and sentence-translation. }\end{array}$ & $\begin{array}{l}\text { To enable the students to } \\
\text { grasp new words and } \\
\text { expressions required by the } \\
\text { syllabus. }\end{array}$ \\
\hline $\begin{array}{c}25 \\
\text { minutes }\end{array}$ & Textual analysis & $\begin{array}{l}\text { The teacher reads the text paragraph by } \\
\text { paragraph, and explains difficult language } \\
\text { points. }\end{array}$ & $\begin{array}{l}\text { To enable the students } \\
\text { understand the text better. }\end{array}$ \\
\hline $\begin{array}{c}10 \\
\text { minutes }\end{array}$ & $\begin{array}{l}\text { The teacher elaborates the } \\
\text { general idea of the text and the } \\
\text { overall structure }\end{array}$ & $\begin{array}{l}\text { By question--asking and answering, } \\
\text { sometimes answering in chorus, the teacher } \\
\text { helps the student grasp the gist and feature } \\
\text { of textual structure of the text. }\end{array}$ & \\
\hline $\begin{array}{c}8 \\
\text { minutes }\end{array}$ & $\begin{array}{l}\text { The teacher helps the student } \\
\text { learn some writing strategies }\end{array}$ & $\begin{array}{l}\text { Using the previous textual analysis, the } \\
\text { teacher gives students instructions on how } \\
\text { to write an exposition. }\end{array}$ & $\begin{array}{l}\text { To encourage and train } \\
\text { student with writing strategies } \\
\text { in English. }\end{array}$ \\
\hline $\begin{array}{c}2 \\
\text { minutes }\end{array}$ & Homework & $\begin{array}{l}\text { Students are given a series of exercises } \\
\text { on vocabulary, structure, reading } \\
\text { comprehension and writing. }\end{array}$ & $\begin{array}{l}\text { To consolidate what the } \\
\text { students have learned. }\end{array}$ \\
\hline
\end{tabular}

\section{TEAChing Plan ON How to CONDUCt LearneR- Centered Class}

\section{A. Rationale for the plan}

In a learner-centered class, the teacher creates a supportive environment in which learners can take initiative in choosing what and how they want to learn. The teacher does not give up control of the classroom, but rather structures and orders the learning process, guiding and giving feedback to learners so that their needs, as well as the needs of the workplace, are addressed. The following are characteristics of learner-centered classrooms (Burkart, 1998):

What happens in the language classroom is a negotiated process between learners and the teacher. Problem-solving exercises should be prominent in any classroom. When the classroom atmosphere is collaborative, the teacher becomes facilitator, moderator, group leader, coach, manager of processes and procedures, giver of feedback, and partner in learning. This is true whether the teacher has planned a whole-class, small-group, paired, or individual activity.
In managing communicative situations in a learner-centered environment, the teacher sets the stage for learners to experiment with language, negotiate meaning, make mistakes, and monitor and evaluate their own language learning progress. This does not mean that the teacher never corrects errors; it means that the teacher knows when and how to deal with error correction and can help learners understand when errors will interfere with effective, comprehensible communication.

The teacher adopts a whole language orientation-integrating listening, speaking, reading, and writing--to reflect natural language use. The teacher also chooses activities that help learners transfer what they learn in the classroom to the worlds in which they live. Furthermore, the teacher treats the learning of grammar as a discovery process, with a focus on understanding the rules for language only after learners have already used and internalized the language. And the teacher has to integrate new cultural skills with new linguistic skills. Learners acquire new language and cultural behaviors appropriate to the language environment, and make it become a less strange and frightening environment. 


\section{B. General Framework for the Class Plan}

The lesson plan and supporting activities are designed for the students with the general framework of learner-centered pedagogy.

Text: Public Attitude towards Science (see AppendixIII)

Type of class: Intensive English Class (for class B)

Objectives of the lesson:

- language oriented objective: to help the students grasp key language points embodied in the text;

- knowledge oriented objective: to learn what is the appropriate attitude to science;

- skill oriented objective: to develop listening, speaking, reading, and writing skills.

TABLE 2. Curriculum

\begin{tabular}{|c|c|c|c|}
\hline $\begin{array}{c}\text { Time } \\
\text { Duration } \\
\end{array}$ & $\begin{array}{l}\text { Lesson } \\
\text { Procedure/Activities } \\
\end{array}$ & Description & Purpose \\
\hline $\begin{array}{c}10 \\
\text { minutes }\end{array}$ & 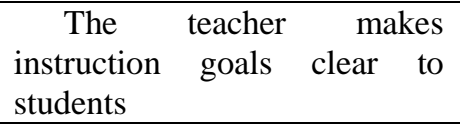 & $\begin{array}{l}\text { To set the instructional goals by asking what are } \\
\text { the students' attitude to science, and putting them on } \\
\text { board. }\end{array}$ & $\begin{array}{l}\text { To make the goals } \\
\text { explicit to students. }\end{array}$ \\
\hline $\begin{array}{c}10 \\
\text { minutes }\end{array}$ & $\begin{array}{l}\text { To introduce the text by } \\
\text { students' presentation }\end{array}$ & $\begin{array}{l}\text { Each group arranges one student to deliver their } \\
\text { findings in the preview tasks of the background } \\
\text { information to the whole class. The teacher makes } \\
\text { some comments when necessary. }\end{array}$ & $\begin{array}{l}\text { To help students } \\
\text { understand the text in } \\
\text { a more sensible way. }\end{array}$ \\
\hline $\begin{array}{c}20 \\
\text { minutes }\end{array}$ & $\begin{array}{l}\text { Vocabulary study via the } \\
\text { way of students' performance }\end{array}$ & $\begin{array}{l}\text { To encourage students to become teachers. To } \\
\text { give students the opportunities to choose words and } \\
\text { expressions from the vocabulary list to teach other } \\
\text { students in class. The success of the students' } \\
\text { presentation is measured by the response and } \\
\text { feedback of the other students. }\end{array}$ & $\begin{array}{l}\text { To enable the } \\
\text { students grasp new } \\
\text { words and expressions } \\
\text { required by the } \\
\text { syllabus. }\end{array}$ \\
\hline $\begin{array}{c}5 \\
\text { minutes }\end{array}$ & The teacher's comments & & - \\
\hline $\begin{array}{c}3 \\
\text { minutes }\end{array}$ & $\begin{array}{l}\text { The students perform silent } \\
\text { reading of the text. }\end{array}$ & & $\begin{array}{l}\text { To } \\
\text { students for } \begin{array}{r}\text { prepare } \\
\text { some }\end{array} \\
\text { open-ended questions. }\end{array}$ \\
\hline $\begin{array}{c}12 \\
\text { minutes }\end{array}$ & $\begin{array}{l}\text { The teacher asks students } \\
\text { those open-ended questions for } \\
\text { the text. }\end{array}$ & $\begin{array}{l}\text { E.g. 1. What is the attitude of some people to the } \\
\text { changes brought about by science and technology? } \\
\text { 2. What limited role can books, magazines and } \\
\text { televisions play in popularizing scientific ideas? }\end{array}$ & $\begin{array}{l}\text { To direct the } \\
\text { students attention to } \\
\text { the important points in } \\
\text { the text. }\end{array}$ \\
\hline $\begin{array}{c}10 \\
\text { minutes }\end{array}$ & $\begin{array}{l}\text { The students themselves } \\
\text { write their own questions. }\end{array}$ & $\begin{array}{l}\text { To divide the class into small groups and ask } \\
\text { them to write their own questions for the text, } \\
\text { exchanging these questions with other groups to be } \\
\text { answered and discussed. }\end{array}$ & $\begin{array}{l}\text { To } \\
\text { students' } \\
\text { understanding } \text { of the } \\
\text { text }\end{array}$ \\
\hline $\begin{array}{c}10 \\
\text { minutes }\end{array}$ & $\begin{array}{l}\text { The students carry out pair } \\
\text { work and group work. }\end{array}$ & $\begin{array}{l}\text { The students dramatize and discuss the main idea, } \\
\text { structure of the text and the writing strategy for an } \\
\text { exposition. }\end{array}$ & $\begin{array}{l}\text { To stimulate the } \\
\text { students to produce } \\
\text { their own versions } \\
\text { concerning the attitude } \\
\text { towards science. To } \\
\text { train students in the } \\
\text { skill of writing an } \\
\text { exposition. }\end{array}$ \\
\hline $\begin{array}{c}10 \\
\text { minutes }\end{array}$ & $\begin{array}{l}\text { The teacher evaluates the } \\
\text { students' performance. }\end{array}$ & $\begin{array}{l}\text { The teacher evaluates students' work and offers } \\
\text { suggestions for further improvements. }\end{array}$ & $\begin{array}{l}\text { To encourage the } \\
\text { students and motivate } \\
\text { their desires to learn. }\end{array}$ \\
\hline
\end{tabular}

Length of class: 90 minutes

Before class: Divide the class into several groups. Ask each of them to choose one preview task to do: background information of Stephen Hawking; introduction to Albert Einstein; vocabulary work; creating their own questions for the comprehension of the text; etc.

Before class, students have to do many writing tasks such as the preparation work for the background information, and they also have to do many translation tasks as studying vocabulary before and in class, so they are not assigned to additional writing and translation homework after class. 


\section{Classroom Activities}

Various types of exercises and activities can be used in a learner-centered environment. These include question and answer, matching, identification, interview, fill-in, labeling, and alphabetizing; using charts and graphs; doing a Total Physical Response (TPR) activity; playing games; creating role-plays and simulations; developing a Language Experience Approach (LEA) story; or writing in a dialogue journal. (See Holt, 1995, and Peyton and Crandall, 1995, for a discussion of these and other adult ESL class activities.)

\section{The EFFECT OF TeACHING Methodology ON STUDENTS WITH DIFFERENT LEARNING STYLES}

\section{A. Correlation between Teaching Methodology and Students' Proficiency}

In order to find out the correlation between teaching methodology and students' proficiency, two tests are conducted at the beginning and the end of one semester respectively, namely the pre-test and the post-test (see Appendix IV ). That is to say, at the beginning of the semester, a pre-test is given to class $\mathrm{A}$, which is taught by teacher-centered teaching methodology, and the same test is also given to class B, which is taught by learner-centered teaching methodology. Then at the end of the semester, a post-test is given to both class A and B. Then the raw scores of the two tests done by students from both class A and B are checked out. These data are processed by the SPSS with the result that the students' scores are distributed normally, which is coincident with Normal Distribution. This means the results of the tests are valid and reasonable. (as shown in the following figures).

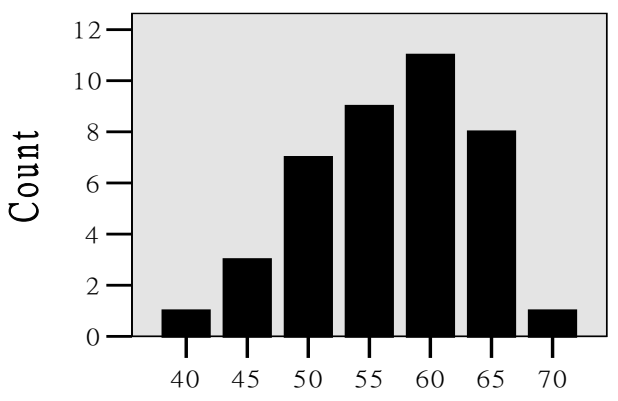

Figure 1 pre-test scores in teacher-centered class

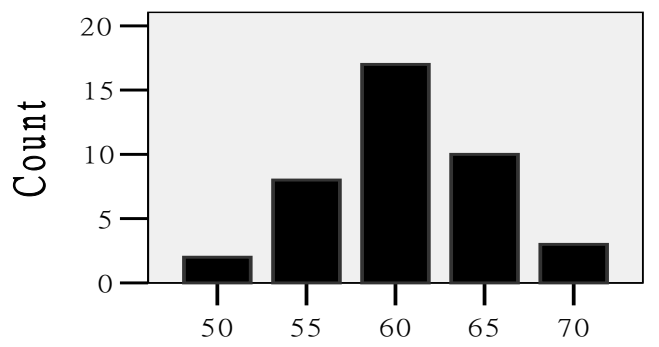

; Figure2 post-test scores in teacher-centered class

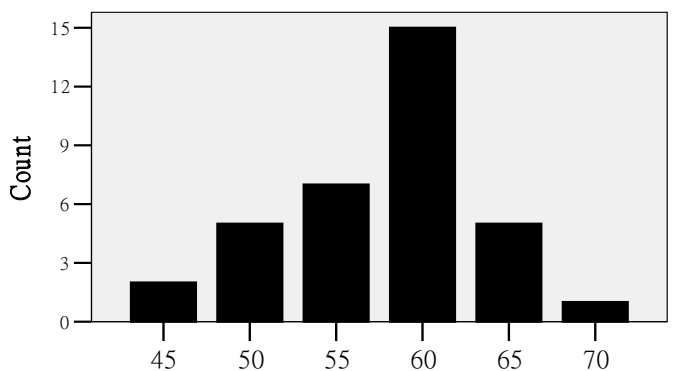

Figure 3 pre-test scores in learner-centered class

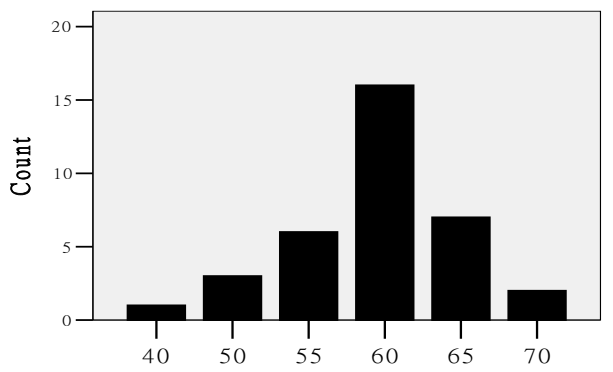

Figure 4 post-test scores in learner-centered class

The average scores of the two tests for Class A and Class B are also examined. As it is shown in Diagram 1-4, the increase of the average score of the post-test over that of the pre-test in Class A is more than twice as much as that in Class B. Students from two parallel classes, using the same learning materials for the same period of time, have made different improvement in their learning of English. The only difference existed among these two groups of students is that they receive different teaching methodologies. The result indicates that different teaching methodologies can influence students' foreign language proficiency to some extent. It can be concluded that there is a correlation between teaching methodologies and students' proficiency.

\section{B. The Effectiveness of Teaching Methodology on Students of Different Learning Styles}

In order to find out the relations among the effectiveness of teaching methodology and students of different learning styles, the results of the pre-test and post-test of each class are analyzed. Attentions are mainly paid to those students who prefer visual, kinesthetic/ tactile, and individual learning styles, for these students stand for the majority. And the results can be seen in follow Figure :

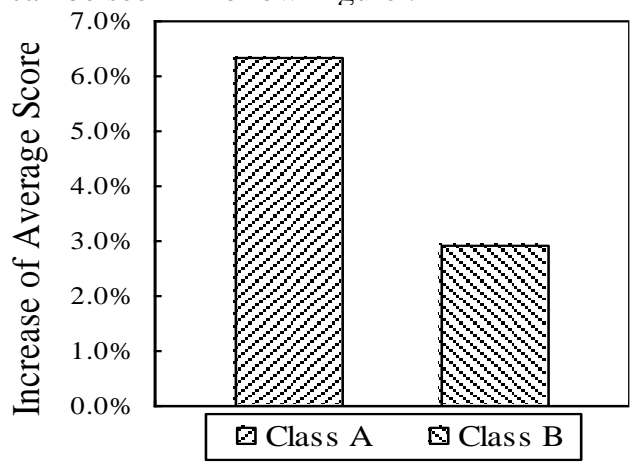

Figure 5 Increase of Average Score 
TABLE 3. The statistics indicates

\begin{tabular}{|c|c|c|c|c|c|c|}
\hline \multirow{2}{*}{$\begin{array}{l}\text { whole class } \\
\text { Score }\end{array}$} & \multicolumn{3}{|c|}{ Class A (40) } & \multicolumn{3}{|c|}{ Class B (35) } \\
\hline & pre & post & diff percentage & pre & post & $\begin{array}{c}\text { diff } \\
\text { percentage }\end{array}$ \\
\hline Listening & 16.88 & 17.38 & $2.96 \%$ & 16.37 & 17.71 & $8.20 \%$ \\
\hline Reading & 30.75 & 33.10 & $7.64 \%$ & 32.46 & 32.34 & $-0.35 \%$ \\
\hline
\end{tabular}

\begin{tabular}{|c|c|c|c|c|c|c|}
\hline \multirow[b]{3}{*}{ Score } & \multicolumn{3}{|c|}{ Class A (40) } & \multicolumn{3}{|c|}{ Class B (35) } \\
\hline & \multicolumn{2}{|c|}{ average } & \multirow{2}{*}{ diff percentage } & \multicolumn{2}{|c|}{ average } & \multirow{2}{*}{$\begin{array}{c}\text { diff } \\
\text { percentage }\end{array}$} \\
\hline & pre & post & & pre & post & \\
\hline Listening & 16.21 & 18.14 & $11.91 \%$ & 15.83 & 18.08 & $\%{ }^{14.21}$ \\
\hline Reading & 29.29 & 32.14 & $9.73 \%$ & 32.67 & 33.17 & $1.53 \%$ \\
\hline Writing & 10.50 & 10.93 & $4.10 \%$ & 11.00 & 11.42 & $3.82 \%$ \\
\hline Total & 56.00 & 61.21 & $9.30 \%$ & 59.50 & 62.67 & $5.33 \%$ \\
\hline
\end{tabular}

T/K style

\begin{tabular}{|c|c|c|c|c|c|c|}
\hline \multirow[b]{3}{*}{ Score } & \multicolumn{3}{|c|}{ Class A (40) } & \multicolumn{3}{|c|}{ Class B (35) } \\
\hline & \multicolumn{2}{|c|}{ average } & \multirow{2}{*}{ diff percentage } & \multicolumn{2}{|c|}{ average } & \multirow{2}{*}{$\begin{array}{c}\text { diff } \\
\text { percentage }\end{array}$} \\
\hline & pre & post & & pre & post & \\
\hline Reading & 30.00 & 33.22 & $10.73 \%$ & 33.58 & 33.47 & $-0.33 \%$ \\
\hline Total & 58.00 & 62.13 & $7.12 \%$ & 61.95 & 63.95 & $3.23 \%$ \\
\hline
\end{tabular}

I style

\begin{tabular}{|c|c|c|c|c|c|c|}
\hline \multirow[b]{2}{*}{ Score } & \multicolumn{3}{|c|}{ Class A (40) } & \multicolumn{3}{|c|}{ Class B (35) } \\
\hline & pre & post & diff percentage & pre & post & $\begin{array}{c}\text { diff } \\
\text { percentage }\end{array}$ \\
\hline Listening & 16.78 & 16.94 & $0.95 \%$ & 15.46 & 16.62 & $7.50 \%$ \\
\hline Reading & 30.22 & 32.22 & $6.62 \%$ & 30.92 & 31.85 & $3.01 \%$ \\
\hline
\end{tabular}

The statistics indicates that:

The general improvement made by students in teachercentered class is better than those in learner-centered class (diff percentage for class A: $6.32 \%$ and diff percentage for class B: $2.92 \%$ )

In teacher-centered class

Those visual students make obvious progress in English listening comprehension and reading comprehension (diff percentage: $11.91 \%$ and $9.73 \%$ ).

The tactile students can make obvious progress in reading ability (diff percentage: $10.73 \%$ ), but no progress or slight progress in listening and writing abilities (diff percentage: $1.01 \%$ and $6.65 \%$ ).

Those individual students only have apparent progress in writing ability (diff percentage: $11.09 \%$ ), while as to reading ability, only slight progress can be seen (diff percentage: $6.62 \%$ ); and when it comes to listening comprehension ability, they make very limited progress (diff percentage: $0.95 \%)$.

In learner-centered class

Visual students can advance considerably in listening ability (diff percentage: $14.21 \%$ ). 
The kinesthetic/tactile students can also make obvious progress in listening (diff percentage: $11.09 \%$ ); but in the aspect of reading ability, they even retrogress a little (diff percentage: $-0.33 \%$ ).

Individual students do not seem to have moved big step forward in these three aspects (diff percentage: $7.50 \%$, $3.01 \%$ and $6.05 \%$ ).

The following are some accounts for the statistical results:

In general, students in teacher-centered class have made greater improvement in their over-all English proficiency than those in learner-centered class. Teacher-centered teaching methodology is still more fitted for today's college English teaching and learning, especially for those first-year college students. With the help of this teaching methodology, students seem to be more capable of absorbing and digesting what they have received. These statistical results further echo what Jere Brophy and Thomas Good said: "students achieve more when they spend most of their time being taught or supervised by their teachers rather than working on their own."

As to students' listening proficiency

In learner-centered class, students of all these styles can make some progress. Among them, the visual students advance the most obviously, while the individual students' progress is less distinctive. This shows that learner-centered teaching methodology could be very effective in improving students' listening ability. The in-class student activities such as oral presentation, discussion, group-work, or role-play etc., can stimulate students' motivation to do more practice in listening and can help or encourage them to improve their listening proficiency.

On the other hand, among students in teacher-centered class, only visual students have made comparatively greater progress, while the kinesthetic and tactile students just move forward a little bit. These research results prove that students can hardly take advantage of this teaching methodology in strengthening their abilities in English listening; esp., those individual students who prefer to learn alone, do not like to work with others, and even are unwilling to cooperate with their classmates and teachers well, can not successfully obtain the opportunities in teachers instructions and classroom activities. The kinesthetic and tactile students, whose performance is a little better than individual students, because of their active motivation, can engage themselves in teachers' delivery of information and can facilitate their own listening ability to some extent.

Therefore, both teacher-centered and learner-centered methodology can contribute a lot to improving the listening ability of visual students; at the same time, learner-centered methodology could be much more helpful to the improvement of the listening ability of kinesthetic/tactile and individual students than teacher-centered methodology.

As to students' reading proficiency

The teacher-centered class is more effective in improving students' reading ability, no matter what their style preferences are. Most students still need teachers' instructions and detailed analysis to inform them about reading strategies and skills, otherwise they may not be able to learn them systematically and effectively, and can not apply those strategies and skills fully to their reading practice. In addition, kinesthetic and tactile students of this class have comparatively better performance in reading proficiency. This can identify that those students who are mentally active and want to do some "hands-on" work could make better improvement in English reading abilities.

In the learner-centered class, most students' test scores do not show any progress in the aspect of reading, even for those visual ones, and some of them seem to retrogress a little. Generally, the students can not grasp the reading strategies and skills without teachers' all-round comprehensive display.

As to writing proficiency, which is another important ability in students' English proficiency

In general, students in both classes do not show very significant advance in their writing abilities.

The only exception in the improvement of writing is the individual students in teacher-centered class who have made considerable progress in their writing abilities. One reason for this may be that with the teachers' detailed guidance and help, the individual students who psychologically prefer to work/ learn alone, can do well in the training of writing ability. What is more important is that the progress in writing ability depends on systematical training and a lot of practices.

In teacher-centered class, visual students may not draw much attention to writing practice, though they could listen attentively to teachers' instructions. And the kinesthetic and tactile students may lack the patience with the deep research in writing strategies or format. In learner-centered class, the average score of their writing proficiency do not show apparent progress by the comparison of the scores of their pre-test and post-test. This may verify that learner-centered teaching methodology does not cater to the improvement of students' writing abilities. Students could not have clear idea of learning writing strategies in order to improve their writing skills with their autonomous study.

In addition, writing ability is one that needs longer time to develop. It requires long time accumulation of vocabulary, sense of language, structure patterns and strategies. So students can not make much progress in a comparatively short time, like one semester. Much more differences can probably be seen, if the time span of teaching progress could be prolonged.

From the results of the diagram analysis and discussions, it can be seen that students' learning style is a complicated topic to be researched on. Together considered with teaching methodologies, the above studies of students' learning styles show some regularity in performing teaching practice with reference to students with different style preferences. This can result in some implications in today's college English pedagogy.

\section{CONCLUSION}

Researches in this paper have provided some empirical evidence to indicate that college students exhibit distinctive learning style characteristics and also that they reflect differently to different teaching methodologies. Then the discussions on the significance of matching teaching 
methodologies and learning styles in today's college English teaching are suggested. To understand and respect individual's diverse learning styles, it is suggested that the teacher employs instruments to identify students' learning styles and provides instructional alternatives to address their differences, and then the teacher plans lessons to match students' learning styles while at the same time to encourage students to diversify their learning style preferences. By doing this the teacher can assist the students in becoming more effective language learners.

\section{ACKNOWLEDGEMENT}

Research on the Development of Hidden Curriculum of University English Teaching, Jilin Province Social Science Fund Project, No. 2013WY13

\section{Reference}

[1] Siler, Carl R. Spatial Dynamics: An Alternative Teaching Tool in the Social Studies. ERIC Clearinghouse for Social Studies, 1998, 179180 .
[2] Smith, L. and Renzulli, J. Learning Style Preference: A Practical Approach for Classroom Teachers. Theory into Practice, 1984, 23/1, 45-50.

[3] Stebbins, C. Culture-specific Perceptual Learning Style Preferences of Postsecondary Students of English as a Second Language. In. Reid, J. M (Ed.), Learning Styles in the ESL/EFL Classroom. New York: Heinle and Heinle Publishers, 1995, 108-117.

[4] Sue, D. W. and Kirk, B. A. Psychological Characteristics of ChineseAmerican Students. Journal of Counseling Psychology, 1990, 19, 471-478.

[5] Tyacke, M. Learning Style Diversity and the Reading Class: Curriculum Design and Assessment. In J. M. Reid (Ed.), Understanding Learning Styles in the Second Language Classroom. USA: Prentice Hall Regents, 1998, 34-45.

[6] Wallace, B., and Oxford, R. L. Disparity in Learning Styles and Teaching Styles in the ESL Classroom: Does This Mean War?" AMTESOL Journal, 1992, 1, 45-68.

[7] Willing, K. Learning Styles in Adult Immigrant Education. Research Series (Ed. David Nunan). Australia: National Curriculum Research Center: Adult Migrant Education Programme, 1988, 102-130. 